\author{
International Journal of Sustainable Development \& World \\ Policy \\ 2021 Vol. 10, No. 1, pp. 25-37. \\ $\operatorname{ISSN}(e): 2305-705 \mathrm{X}$ \\ $\operatorname{ISSN}(p): 2306-9929$ \\ DOI: 10.18488/journal.26.2021.101.25.37 \\ (C) 2021 Conscientia Beam. All Rights Reserved. \\ check for
}

\title{
CSR THEMES QUALITY, GOOD CORPORATE GOVERNANCE, AND EARNINGS MANAGEMENT: EVIDENCE FROM INDONESIA
}

Tommy Andrian ${ }^{1+}$ Etty Murwaningsari ${ }^{2}$

\author{
${ }^{\prime}$ Doctoral Student, Faculty of Economics $\&$ Business, Trisakti University, \\ Indonesia. \\ Email:tommyandrian28@gmail.com Tel:+6281295921222 \\ 'Accounting Department, Faculty of Economics \& Business, Trisakti \\ University, Indonesia. \\ Email:ettynasser@yahoo.com
}

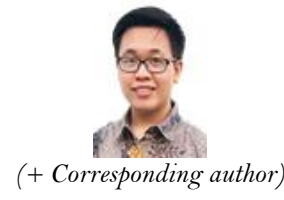

Article History

Received: 15 February 2021

Revised: 18 March 2021

Accepted: 21 April 2021

Published: 31 May 202

Keywords

CSR themes quality Corporate social responsibility disclosure

Good corporate governance

Earnings management

Consumer goods industry

Indonesia.

JEL Classification: M41, Q56

\begin{abstract}
The study aims to investigate the effect of CSR themes quality on earnings management. The paper also examines the moderating effect of good corporate governance on the relationship between CSR themes quality and earnings management. The study uses a quantitative approach and panel data regression using 170 firm-year observations of consumer goods industries listed in IDX for 2015-2019. This study uses the measurement of the CSRD using a combined corporate social responsibility matrix from three countries and examining each theme (environment, energy, human resources, community development, other CSR activities) in CSR to know which pieces are involved can reduce EM practice. The result suggests product \& innovation and community development have a negative and significant influence on earnings management. This research also shows that the positive effect of community development and others CSR activities on earnings management is strengthened with good corporate governance. This proves that companies with higher earnings management levels use CSR activities to disguise opportunistic managerial behavior. Still, companies that make disclosures on product \& innovation and community development activities can limit their earnings management. Then, the implementation of GCG, which is related to transparency, will cause less motivation to practice earnings management.
\end{abstract}

Contribution/Originality: This study contributes to existing literature by investigating the effect of CSR themes quality on earnings management.

\section{INTRODUCTION}

Financial reports are a meaningful instrument in describing the performance of an industry. One of the significant components of the financial statements is a component of profit. Profit is used to measure the performance and increase of an entity. Profit data in financial reports is the primary data in making investment decisions. The earnings data is often used as manipulation material for management actions to maximize satisfaction. This action was tried for its interests by making specific accounting policies so that profits could be adjusted, increased, or decreased according to their wishes, and the attitude of the management was known as Earnings Management (Abduh \& Rusliati, 2018). Over the last few decades, the business world has been influenced by a growing understanding of industrial social responsibility. In practice, industries that practice CSR activities are bound to share transparent and reliable financial data (Kim, Park, \& Wier, 2012) and display a commitment to 
ethical and accountable attitudes (Jones, 1995). However, there is a reason that CSR can be used as a mechanism to achieve managers' self-interest goals by distorting income data (Almahrog, Aribi, \& Arun, 2018).

Because earnings management (EM) is perceived in the literature as an ethical issue, some research has attempted to explore whether EM and CSR are interrelated. However, some research has suggested that EM and CSR are negatively related. Christensen (2016); Almahrog et al. (2018); Kim, Seol, and Kang (2018); Sial, Chunmei, and Khuong (2019) broadly show that an industry with a strong commitment towards CSR tends not to participate in EM. On the other hand, Jouber (2019); Mohmed, Flynn, and Grey (2019); Muttakin, Khan, and Azim (2015) and Scholtens and Kang (2013) create a positive bond between EM and CSR as well as suggests that larger-level industries use EM for CSR activities to hide managerial opportunism.

So far, researchers have found few research that uses good corporate governance to strengthen corporate social responsibility ties to earnings management applications in the industry. Some studies have studied the direct relationship between GCG and earnings management and have shown positive results, namely (Abduh \& Rusliati, 2018; Larastomo, Perdana, Triatmoko, \& Sudaryono, 2016) who reported on the industry. Those who have practiced good corporate governance can create an excellent industrial, financial performance not to affect earnings management applications. On the other hand, the research tried by Mersni and Othman (2016); Mahdalena, Putra, and Arnawati Putri (2019) have negative results which report that many earnings management practices require the industry to practice good corporate governance to minimize, let alone prevent it from overcoming agency problems (agency theory) and is believed to be able to reduce earnings management practices.

Researchers use the good corporate governance variable as a moderating variable because problems that arise between agents (managers) and principals (owners) will increase moral hazard, such as managers not carrying out responsibilities as stated in their work contracts. Hence, GCG implementation plays a strategic role in helping business credibility. Company processes that will encourage disclosure of corporate social responsibility relate to one of the principles of GCG, namely transparency, and can suppress earnings management practices in the company. Based on this basis in this study, we want to use good corporate governance as a moderating variable. This study also uses control variables, such as return on assets, board meetings, and board of directors, because several previous studies have shown significant results on earnings management (Rusdiyanto \& Narsa, 2020; Sastrawati \& Hatane, 2016). Several other factors may affect the dependent variable. If these factors are not well controlled, they can affect the existing dependent variable, thereby reducing the study's accuracy so that the researcher uses these variables as control variables.

Given that empirical findings remain inconclusive, further research is needed to understand how CSR and GCG initiatives can affect the quality of corporate reporting by reducing EM practices (Almahrog et al., 2018; Mersni \& Othman, 2016). Therefore, in connection with the description above, this study seeks to fill this gap by examining the effect of CSRD on earnings management and examining each theme (environment, energy, human resources, community development, other CSR activities) in CSR to know which themes are involved can reduce EM practice. In addition, this paper wants to know that the GCG variable can moderate the CSRD and EM variables.

\section{LITERATURE REVIEW}

\subsection{Agency Theory}

According to Jensen and Meckling (1976), the problem is that there are often differences in interests between the two parties (between investors and company management). These differences result in decisions made by company management that do not accommodate the interests of the shareholders. Earnings management is a method used by managers to systematically and deliberately influence earnings figures by selecting specific accounting policies and accounting procedures to benefit various parties. Given that EM is more likely to be intertwined with big data asymmetry, signaling theory assumes that CSR data is used as a facility to reduce data 
symmetry (agency problems) between industries and their investors. Therefore, it comes from the idea that CSR data is a valuable tool for lowering data asymmetry (Beekes, Brown, \& Zhang, 2012).

\subsection{Stakeholder Theory}

Stakeholder theory says that the industry is not an entity that only operates for its interests but is obliged to share benefits for its stakeholders. Thus, the existence of an enterprise is strongly influenced by the support provided by stakeholders to the industry (Ulum, Ghozali, \& Chariri, 2008). The current theory of industrial stakeholders is responsible for the profit of the sector alone and all stakeholders who have the consequences of the strategies and policies adopted by the industry. Stakeholder theory describes the bonds between stakeholders and the data they can (Grimaldi, Caragnano, Zito, \& Mariani, 2020). Managers can be employed not only as principals but also as agents of other stakeholders. Managers can take earnings management actions to obtain personal benefits derived from different stakeholders. However, stakeholders want to respond to management actions related to their interests.

\subsection{Corporate Social Responsibility Disclosure Eं Earnings Management}

The disclosure of corporate social responsibility tends to affect earnings management negatively. The negative effect is convincing that industries that disclose CSR do not often implement earnings management applications (Gras-Gil, Palacios Manzano, \& Hernández Fernández, 2016). In line with this, research was conducted by Scholtens and Kang (2013). Typically, the purpose of the industry expresses the social responsibility and the industrial area to form a good image or reputation of the industry. To make this matter happen, managers are more vigilant and stay away from fraud and manipulations such as earnings management. Therefore, the level of CSR disclosure continues to be good until the earnings management application continues to shrink. Based on this basis, the following hypothesis can be formulated:

H1: Corporate social responsibility disclosure has a negative effect on earnings management.

According to Li and Zaiats (2017) regarding the management of the living environment, a living environment is a spatial unit using all objects, resources, conditions \& living things, including human beings and their behavior, which affect the continuity of life and the welfare of humans and other living creatures; The management of the living environment is an integrated effort to preserve the functions of the living environment which includes policies on the arrangement, utilization, development, maintenance, restoration, supervision and control of the live environment. The disclosure of social responsibility activities related to environmental aspects in the annual report will create more transparent financial information for parties who use financial statements. Transparency in terms of the environment concerning the living environment directly adjacent to the community will make management limit its profit management practices. Based on this basis, the following hypothesis can be formulated:

H2: Corporate social responsibility disclosure as proxied by the environment has a negative effect on earnings management.

According to António and Dos Santos (2019), energy has a scientific definition of working or moving. This energy allows any activity to take place. In everyday life, the most familiar power we know is electricity and fuel. The disclosure of social responsibility activities related to the aspects of energy requires the company to be transparent in all aspects of the business, including decisions on disclosing the power the company uses. Thus, disclosing CSR in terms of calculated energy will make management limit its profit management practices. Based on this basis, the following hypothesis can be formulated:

H3: Corporate social responsibility disclosure as proxied by energy has a negative effect on earnings management.

Human resources (HR) are productive individuals who work as a driving force for an organization, both in institutions and companies that function as assets so that their abilities must be trained and developed (Utamy, Ahmad, \& Eddy, 2020). The existence of disclosure of social responsibility activities related to aspects of human resources expresses the company's concern for their human resources. This requires the company to be transparent 
so that management limits the use of its profit management practices. Based on this basis, the following hypothesis can be formulated:

H4: Corporate social responsibility disclosure as proxied by human resources has a negative effect on earnings management.

According to Atmaja (2020) be able to achieve a competitive advantage can be done based on three inconsistent parts, namely: cost leadership, differentiation in terms of production of products or services that are believed to be units in the industry, and adding quality or products, and emphasis on obtaining the output of products and services that meet the needs of a mini group of consumers using the lowest or highest prices on the market. The existence of disclosure of social responsibility activities related to aspects of Product, Services, Safety, \& Innovation will create a company financial report prepared to reduce manipulation by management. Based on this basis, the following hypothesis can be formulated:

H5: Corporate social responsibility disclosure as proxied by Product, Services, Safety, E Innovation has a negative effect on earnings management.

The high performance of the CSR \& community development (CD) program will be seen how the commitment, policies, and actions of the corporation towards their stakeholders or mainly in the closest community (Acharya \& Patnaik, 2018). In turn, the performance of the CSR \& CD program can determine how much social legitimacy the stakeholders are, especially the surrounding community, for their commitment, presence, and general corporate actions. One of the social support or rejection of the existence of corporations is very dependent on how corporate responsibilities \& actions towards them can be objectively reflected in CSR \& CD activities. Thus, companies that make disclosures in Community Development can limit the use of their profit management practices. Based on this basis, the following hypothesis can be formulated:

H6: Disclosure of corporate social responsibility as proxied by Community Development has a negative effect on earnings management.

By carrying out CSR activities and discussing other aspects that have not been disclosed in the CSR Themes aspect properly, the business risk of pressure based on social stakeholders on the corporation will be lower. Therefore, this will narrow the gap in profit management practices \& can limit the use of its profit management practices because the disclosure aspects made by the company are more complete. Based on this basis, the following hypothesis can be formulated:

H7: Disclosure of corporate social responsibility as proxied by Others CSR Activities has a negative effect on earnings management.

\subsection{Corporate Social Responsibility Disclosure, Good Corporate Governance E̊ Earnings Management}

Companies that are committed to carrying out CSR activities as a manifestation that managers are responsible for doing what is right, being truthful, ethical, and managing corporate transactions have a negative effect on earnings management practices because companies that are accountable and socially honest consider objectives them to be more transparent, this causes less motivation to enjoy earnings management practices, and this is in line with research conducted by Christensen (2016); Almahrog et al. (2018); Kim et al. (2018). Thus, the implementation of GCG plays a strategic role in helping the credibility of the company's business processes that will encourage disclosure of corporate social responsibility because it is related to one of the principles of GCG, namely transparency, and can suppress earnings management practices in companies, this is in line with the research conducted by Mersni and Othman (2016); Mahdalena et al. (2019). Based on this basis, the following hypothesis can be formulated:

H8: Good corporate governance strengthens the relationship between corporate social responsibility disclosure and earnings management.

The implementation of Good Corporate Governance (GCG), which in this case is related to transparency, will further strengthen the relationship with the disclosure of corporate social responsibility related to environmental 
aspects carried out by companies, such as pollution control, use of recycled materials, waste treatment, and other environmental protection (Wang, Cao, \& Ye, 2018). Thus, it causes less motivation to practice earnings management. Based on this basis, the following hypothesis can be formulated:

H9: Good corporate governance strengthens the relationship between environment and earnings management.

The implementation of Good Corporate Governance (GCG), which in this case is related to transparency, will further strengthen the relationship with the disclosure of corporate social responsibility related to the Energy aspects of the company, such as disclosures related to the company's efforts to reduce energy consumption, save energy, energy policy, and make related voices short-term power (Muñoz-Torres, Fernández-Izquierdo, Rivera-Lirio, \& Escrig-Olmedo, 2019). Thus, it causes less motivation to practice earnings management. Based on this basis, the following hypothesis can be formulated:

H10: Good corporate governance moderates the relationship between Energy and earnings management.

The implementation of Good Corporate Governance (GCG), which in this case is related to transparency, will further strengthen the relationship with the disclosure of corporate social responsibility related to aspects of Human Resources carried out by the company, such as promoting worker safety, fighting discrimination, disclosing the qualifications of the workforce recruited, disclosing the number of employees work within the company, and disclose information on the relationship between management and labor. Thus, it causes less motivation to practice earnings management. Based on this basis, the following hypothesis can be formulated:

H11: Good corporate governance moderates the relationship between Human Resources and earnings management.

The implementation of Good Corporate Governance (GCG), which in this case is related to transparency, will further strengthen the relationship with the disclosure of corporate social responsibility related to aspects of Product, Services, Safety, \& Innovation carried out by the company, such as disclosure of product development information, disclosure that products meet safety standards, and disclosure that there is an increase in cleanliness in product processing (García-Sánchez, Hussain, Khan, \& Martínez-Ferrero, 2020). Thus, it causes less motivation to practice earnings management. Based on this basis, the following hypothesis can be formulated:

H12: Good corporate governance moderates the relationship between Product, Services, Safety, E Innovation with earnings management.

The implementation of Good Corporate Governance (GCG), which in this case is related to transparency, will further strengthen the relationship with the disclosure of corporate social responsibility related to aspects of Community Development carried out by companies, such as disclosures related to company activities to help the community, activities to help victims of natural disasters, and activities village building programs, and other community-related activities. Thus, it causes less motivation to practice earnings management (Hendra, Koesharjono, \& Priantono, 2018). Based on this basis, the following hypothesis can be formulated:

H13: Good corporate governance moderates the relationship between Community Development and earnings management.

The implementation of Good Corporate Governance (GCG), which in this case is related to transparency, will further strengthen the relationship with the disclosure of corporate social responsibility related to aspects of Other CSR Activities carried out by the company, such as disclosing general corporate objectives related to CSR, obtaining CSR awards, the existence of codes ethics, and reveal the presence of applied business ethics (Montani, Perrini, Gervasio, \& Pulcini, 2020). Thus, it causes less motivation to practice earnings management. Based on this basis, the following hypothesis can be formulated:

H14: Good corporate governance moderates the relationship between Others CSR Activities and earnings management.

\section{METHOD}

\subsection{Sampling Method}

The object of this research is consumer goods companies listed on the Indonesia Stock Exchange (IDX) in the period 2015-2019. The data type of this research is panel data, namely a combination of time series using the 
research period from 2015-2019 with a cross-section involving consumer goods companies. This type of research uses quantitative methods. The data used in this study are secondary data obtained from the annual financial reports of the IDX, company website, and sustainability reports. The research variable on corporate social responsibility (CSRD) and good corporate governance emphasize the "disclosure" process on specific subjects in voluntary activities related to disclosure of social responsibility and the implementation of governance that the company has carried out. Reporting tends to refer to "reports," which are used to "disclose" specific topics, such as sustainability and environmental reports, while "disclosure" is to provide information to readers through reports (Gunawan, 2013).

\subsection{Variables $\mathcal{E}^{2}$ Measurement}

EM is an action carried out for its interests by making specific accounting policies so that profits can be adjusted, increased, or decreased according to their wishes. This study uses earnings management as the dependent variable using the conditional revenue model from Stubben (2010) research, namely:

$\Delta$ ARit $=\alpha+\beta 1 \Delta$ Rit $+\beta 2 \Delta$ Rit X SIZEit $+\beta 3 \Delta$ Rit X AGEit $+\beta 4 \Delta$ Rit X AGE_SQit $+\beta 5 \Delta$ Rit X GRR_Pit $+\beta 6 \Delta$ Rit X GRR_Nit $+\beta 7 \Delta$ Rit X GRMit $+\beta 8 \Delta$ Rit X GRM_SQit + eit

Where Account Receivable (AR) is measured by the end of fiscal year account receivable, revenue (R) is calculated by Annual Revenue, the natural log of total assets measures firm size (SIZE) at the end of the fiscal year, firm age (AGE) is measured with the natural log of the age of firm (years), proxies for the operational performance of the company relative to industry competitors, researchers use industry-median-adjusted growth rate in revenues (GRR_P if positive, GRR_N if negative) and the industry-median-adjusted gross margin (GRM) and its square (GRM_SQ).

CSR disclosure is a process of communicating the social and environmental impacts of a company's business activities to stakeholders (Suripto, 2019). This study uses corporate social responsibility disclosure as the independent variable. Measurement of CSR disclosure uses CSR Themes taken from Andrian and Sudibyo (2019) because this study uses the CSR Matrix from 3 countries such as Indonesia, India, and Portugal, which can provide more relevant and comprehensive disclosure items in common with a total of 84 items.

GCG is a system designed to improve company performance in protecting the interests of shareholders and the company's compliance with applicable laws and regulations. This study uses Good Corporate Governance as a moderating variable. Reference in the measurement of good corporate governance issued by the ASEAN corporate governance scorecard and researchers only use one aspect related to disclosure, namely the elements of disclosure and transparency because the researcher wanted to see the extent to which company management carried out its responsibilities and disclosure and transparency with a total of 32 items of the disclosure.

Corporate social responsibility disclosure (CSRD) and good corporate governance (GCG) are measured using a dummy variable; companies that disclose and implement CSRD \& GCG items in the annual financial report or sustainability report will be assigned the number 1 and o (zero) vice versa. For each item disclosed in the company's report, the value is one so that if the company discloses CSR themes, the total will be a total of 84 items and 32 items for GCG. Measurements are then made using an index by calculating the number of items disclosed divided by the total items disclosed (Angelia \& Suryaningsih, 2015).

This study also adds a control variable, namely return on assets (ROA) which is measured by total net income divided by average total assets (Weygandt \& Kieso, 2015) board of meetings (MET) which is calculated by taking into account the number of meetings conducted by the board of directors in one company (Sastrawati \& Hatane, 2016) and the board of directors (BOD) which is measured by taking into account the number of boards of directors with economic and business education divided by the total number of members of the board of director (Burghleh \& Al-Okdeh, 2020). 


\subsection{Research Design}

In this research, the multiple linear regression method is used because there is one dependent variable and more than one independent variable. The multiple linear regression equation used in this study is:

$\mathrm{EM}=\alpha+\beta 1 \mathrm{CSRD}+\beta 2 \mathrm{ENV}+\beta 3 \mathrm{ENG}+\beta 4 \mathrm{HRS}+\beta 5 \mathrm{PSS}+\beta 6 \mathrm{CMD}+\beta 7 \mathrm{OCS}+\beta 8 \mathrm{CSRD} * \mathrm{GCG}+$ $\beta 9 \mathrm{ENV}^{*} \mathrm{GCG}+\beta 10 \mathrm{ENG} \mathrm{GCG}^{+} \beta 11 \mathrm{HRS} * \mathrm{GCG}+\beta 12 \mathrm{PSS} * \mathrm{GCG}+\beta 13 \mathrm{CMD} * \mathrm{GCG}+\beta 14 \mathrm{OCS} * \mathrm{GCG}+\beta 15$ $\mathrm{ROA}+\beta 16 \mathrm{MET}+\beta 17 \mathrm{BOD}+\mathrm{e}$

\section{RESULT AND DISCUSSION}

\subsection{Descriptive Statistics}

The descriptive statistical test in this study includes all research variables, and the results of the descriptive statistics are shown in Table 1 below:

Table-1. Descriptive statistics.

\begin{tabular}{c|c|c|c|c}
\hline Variable & Min & Max & Mean & Std Deviation \\
\hline EM & -4.1300 & 21.6700 & -0.0002 & 1.9431 \\
\hline CSRD & 0.0714 & 0.7262 & 0.4042 & 0.1473 \\
\hline ENV & 0.0769 & 0.9231 & 0.4375 & 0.2089 \\
\hline ENG & 0.1667 & 1.0000 & 0.4304 & 0.2932 \\
\hline HRS & 0.0294 & 0.8529 & 0.3782 & 0.1686 \\
\hline PRD & 0.1250 & 0.8750 & 0.4330 & 0.2142 \\
\hline COM & 0.0714 & 0.6429 & 0.3134 & 0.1532 \\
\hline OTH & 0.1111 & 0.8889 & 0.5862 & 0.2008 \\
\hline GCG & 0.2500 & 0.8750 & 0.6910 & 0.1118 \\
\hline MET & 6.0000 & 81.0000 & 16.264 & 10.5300 \\
\hline BOD & 0.1111 & 1.0000 & 0.5929 & 0.2388 \\
\hline ROA & -0.1598 & 1.1026 & 0.0963 & 0.1440 \\
\hline
\end{tabular}

When monitoring consumer goods companies in 2015-2019, the lowest minimum value was determined by the variable earnings management (EM) -4.1300. According to the classification carried out by Stubben (2010) this value is above the range -0.075 and 0.075 , which indicates that there are companies in the sample that are shown by accrual earnings management. The maximum value is owned by variable earnings management (EM) 21.6700. It is above the range of -0.075 and 0.075 , which indicates that there are companies in the sample told by accrual earnings management. When viewed from comparing the mean and standard deviation in this study, all the variables used have a mean value greater than the standard deviation value. This indicates that the distribution of data used in this study is homogeneous.

\subsection{Correlation Analysis}

This table provides an overview of the correlation between variables used in this study. This analysis is based on 170 research samples from consumer goods industry companies for 2015-2019. The results are shown in Table 2 below: 
International Journal of Sustainable Development \& World Policy, 2021, 10(1): 25-37

\begin{tabular}{|c|c|c|c|c|c|c|c|c|c|c|c|c|}
\hline & $\overline{E M}$ & CSRD & ENV & ENG & HRS & $\begin{array}{l}\text { PRD } \\
\end{array}$ & $\mathrm{COM}$ & OTH & GCG & MET & BOD & ROA \\
\hline EM & 1.00 & $\begin{array}{c}-0.74 * * * \\
(0.00)\end{array}$ & $\begin{array}{c}-0.56^{* * *} \\
(0.00)\end{array}$ & $\begin{array}{c}-0.43^{* *} * \\
(0.00)\end{array}$ & $\begin{array}{l}-0.06 \\
(0.56)\end{array}$ & $\begin{array}{l}-0.14 \\
(0.19)\end{array}$ & $\begin{array}{l}-0.04 \\
(0.73)\end{array}$ & $\begin{array}{c}0.31^{* *} \\
(0.00)\end{array}$ & $\begin{array}{l}-0.07 \\
(0.52)\end{array}$ & $\begin{array}{c}0.38^{* *} * \\
(0.00)\end{array}$ & $\begin{array}{l}-0.08 \\
(0.49)\end{array}$ & $\begin{array}{l}-0.06 \\
(0.54)\end{array}$ \\
\hline CSRD & & 1.00 & $\begin{array}{c}0.51 * * \\
(0.00)\end{array}$ & $\begin{array}{c}0.34^{* *} * \\
(0.00)\end{array}$ & $\begin{array}{c}0.14 \\
(0.20)\end{array}$ & $\begin{array}{c}0.18 \\
(0.93)\end{array}$ & $\begin{array}{c}0.07 \\
(0.55)\end{array}$ & $\begin{array}{c}-.011 \\
0.33\end{array}$ & $\begin{array}{l}0.22^{*} \\
(0.04)\end{array}$ & $\begin{array}{l}-0.15 \\
(0.18)\end{array}$ & $\begin{array}{l}-0.03 \\
(0.82)\end{array}$ & $\begin{array}{c}0.08 \\
(0.46)\end{array}$ \\
\hline ENV & & & 1.00 & $\begin{array}{c}0.16 \\
(0.14)\end{array}$ & $\begin{array}{l}0.24 * \\
(0.03)\end{array}$ & $\begin{array}{c}0.18 \\
(0.09)\end{array}$ & $\begin{array}{c}0.12 \\
(0.29)\end{array}$ & $\begin{array}{l}-0.06 \\
(0.60)\end{array}$ & $\begin{array}{c}0.28^{* *} * \\
(0.00)\end{array}$ & $\begin{array}{l}-0.08 \\
(0.47)\end{array}$ & $\begin{array}{l}-0.04 \\
(0.70)\end{array}$ & $\begin{array}{l}0.22^{*} \\
(0.04)\end{array}$ \\
\hline ENG & & & & 1.00 & $\begin{array}{c}0.07 \\
(0.55)\end{array}$ & $\begin{array}{l}-0.05 \\
(0.66)\end{array}$ & $\begin{array}{c}0.03 \\
(0.82)\end{array}$ & $\begin{array}{l}-0.21 \\
(0.06)\end{array}$ & $\begin{array}{l}-0.09 \\
(0.40)\end{array}$ & $\begin{array}{l}-0.05 \\
(0.67)\end{array}$ & $\begin{array}{c}0.09 \\
(0.39)\end{array}$ & $\begin{array}{c}0.01 \\
(0.92)\end{array}$ \\
\hline HRS & & & & & 1.00 & $\begin{array}{l}0.50^{* * *} \\
(0.00)\end{array}$ & $\begin{array}{c}0.52^{* *} * \\
(0.00)\end{array}$ & $\begin{array}{c}0.44^{* *} * \\
(0.00)\end{array}$ & $\begin{array}{c}0.53^{* * *} \\
(0.00)\end{array}$ & $\begin{array}{c}0.15 \\
(0.17)\end{array}$ & $\begin{array}{c}-0.27^{*} \\
(0.01)\end{array}$ & $\begin{array}{c}0.29^{* *} \\
(0.00)\end{array}$ \\
\hline PRD & & & & & & 1.00 & $\begin{array}{c}0.39^{* *} * \\
(0.00)\end{array}$ & $\begin{array}{c}0.19 \\
(0.08)\end{array}$ & $\begin{array}{c}0.48^{* *} * \\
(0.00)\end{array}$ & $\begin{array}{c}0.19 \\
(0.08)\end{array}$ & $\begin{array}{c}0.06 \\
(0.60) \\
\end{array}$ & $\begin{array}{c}0.09 \\
(0.42) \\
\end{array}$ \\
\hline $\mathrm{COM}$ & & & & & & & 1.00 & $\begin{array}{c}0.12 \\
(0.27)\end{array}$ & $\begin{array}{c}0.42^{*} * \\
(0.00)\end{array}$ & $\begin{array}{c}0.14 \\
(0.20)\end{array}$ & $\begin{array}{l}-0.11 \\
(0.32)\end{array}$ & $\begin{array}{c}0.05 \\
(0.62)\end{array}$ \\
\hline OTH & & & & & & & & 1.00 & $\begin{array}{c}0.33^{* *} * \\
(0.00)\end{array}$ & $\begin{array}{c}0.20 \\
(0.06)\end{array}$ & $\begin{array}{l}-0.01 \\
(0.37)\end{array}$ & $\begin{array}{c}0.20 \\
(0.07)\end{array}$ \\
\hline GCG & & & & & & & & & 1.00 & $\begin{array}{c}0.18 \\
(0.09)\end{array}$ & $\begin{array}{c}-0.33^{* *} \\
(0.00)\end{array}$ & $\begin{array}{c}0.29^{* * *} \\
(0.00)\end{array}$ \\
\hline MET & & & & & & & & & & 1.00 & $\begin{array}{c}0.03 \\
(0.79) \\
\end{array}$ & $\begin{array}{l}-0.04 \\
(0.71)\end{array}$ \\
\hline BOD & & & & & & & & & & & 1.00 & $\begin{array}{l}-0.05 \\
(0.62)\end{array}$ \\
\hline ROA & & & & & & & & & & & & 1.00 \\
\hline
\end{tabular}

Noter

b* $<<0.05$ and *** $<0.01$ correlation is significant at the 0.05 and 0.01 levels respectively, based on two-sided tests. 
The analysis results show that the correlation coefficient of CSRD, ENV, and ENG (-0.74, -0.56, and -0.43) is negative and significant at the 0.01 level. This shows that if assessed as a whole for all CSR themes reflected in the CSRD variable, it will tend to be followed by a decline in earnings management practices. Then, if viewed from the themes individually, companies that make more disclosures related to environmental and energy will tend to be followed by a decrease in earnings management practices. However, the correlation coefficient for OTH (O.31) is positive and significant at the 0.01 level. This shows that companies that carry out more other CSR activities and other themes will tend to be followed by an increase in earnings management practices because they can cover opportunistic managerial attitudes. Other variables have a negative but insignificant correlation.

The analysis results show that the correlation coefficients of ENV, ENG, and GCG (0.51, 0.34, and 0.22) are positive and significant at the 0.01 and 0.05 levels. This shows that if the company focuses on the disclosure of environmental energy and is supported by an adequate implementation of GCG, it will tend to be followed by an increase in CSRD. Then, the results of the analysis of the correlation coefficient of HRS, GCG, and ROA (0.24, 0.28, and 0.22 ) are positive and significant at the 0.01 and 0.05 levels. This shows that human resources, good corporate governance, and adequate return on assets tend to be followed by an increase in environmental disclosures.

\subsection{Classical Assumption Test}

Based on the result, which shows normality tests, the Jarque Bera value is 1.899139 , and the probability value is 0.386908 . This shows $0.386908>0.05$; it can be concluded that the data used in this study are normally distributed. Based on the multicollinearity test results, it can be supposed that the independent variables, moderating variables, and control variables used occur multicollinearity. The test results indicate that HRS and CSRD have a value of $0.92>0.8$. This is because this study using interaction variables so that there will be a correlation between the independent variables that make multicollinearity occur in this study, but this can be ignored because one of the consequences of using interaction variables is the emergence of multicollinearity in the research model (Gujarati, 2012). Based on the result of the autocorrelation test for all variables used in this study with a probability value of $0.9686>0.05$. It can be concluded that there was no autocorrelation in this study. Based on the result of the heteroscedasticity test for all variables used in this study with a probability value of 0.5850 greater than 0.05 , it can be concluded that there is no heteroscedasticity in this study.

\subsection{Regression Result}

The results of the regression in this study are shown in Table 3.

Dependent Variable: Earnings Management (EM). Independent variable: Corporate Social Responsibility Disclosure (CSRD); Environmental (ENV); Energy (ENG); Human Resources (HRS); Product (PRD); Community Development (COM); Other CSR Activities (OTH). Moderating Variable: Good Corporate Governance (GCG)

Then it can be seen that the probability statistic value $\mathrm{F}$ is 0.000 with a significance level below 0.05. From this, it can be concluded that this research model is feasible and can predict the information on earnings management. It can then be seen that the coefficient of determination (adjusted R-square) is 0.7427. This shows that corporate social responsibility quality and good corporate governance can explain the earnings management of $74.27 \%$, while the remaining $25.73 \%$ is explained by other variables not included in this study. The Standard Error of Estimation is 0.5123. This means that the smaller the SEE value, the more precise the regression model in this study is to predict the disclosure of the dependent variable earnings management. 
Table-3. Regression result.

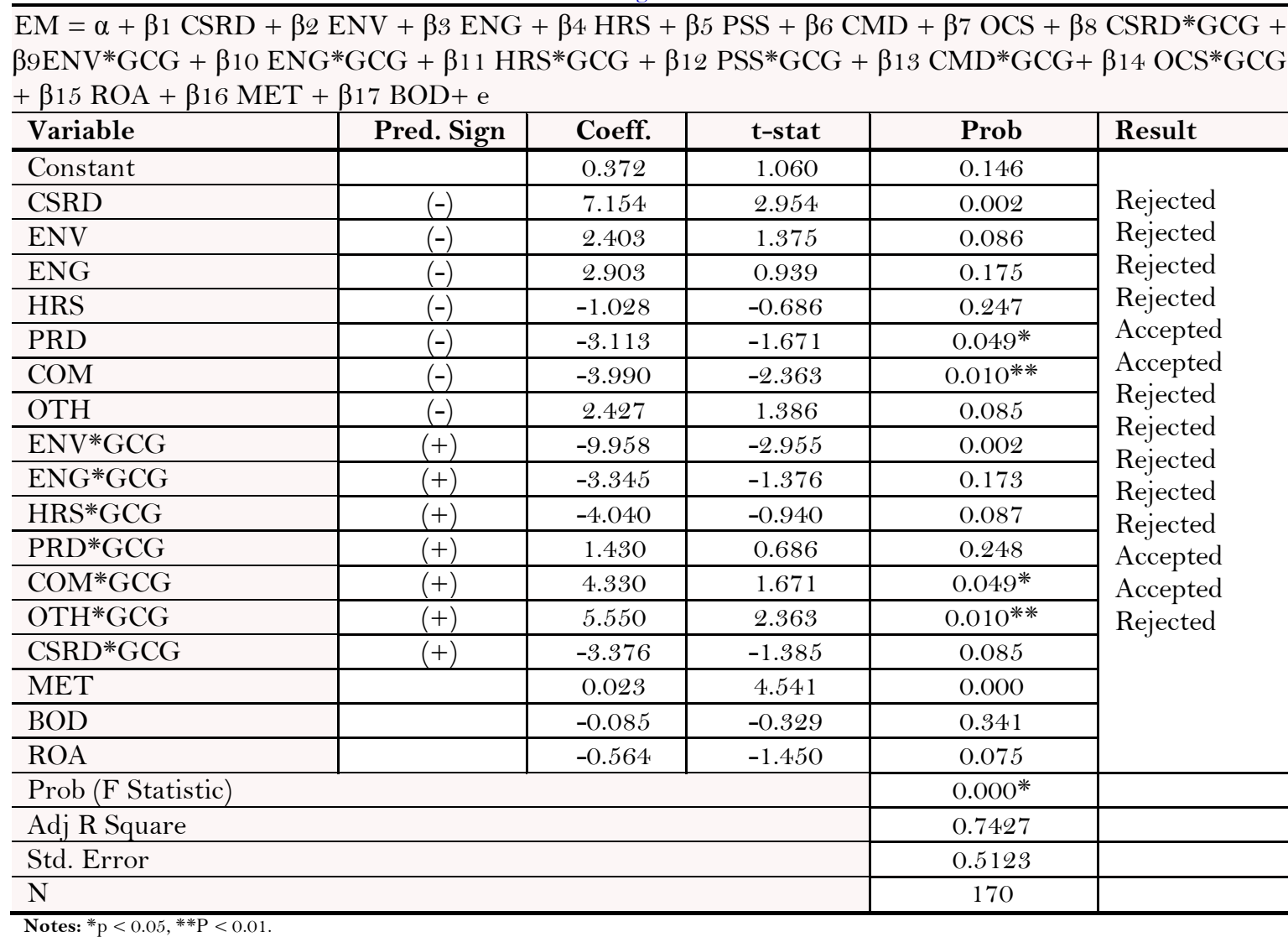

\section{DISCUSSION}

Based on the results of the statistical t-test (t-test), it can be concluded that the variable corporate social responsibility disclosure does not influence earnings management. This is in line with research conducted by Jouber (2019); Mohmed et al. (2019); Muttakin et al. (2015) and Scholtens and Kang (2013) because that companies that manage their earnings upward engage in more CSR activities, perhaps to distract investors from their mistakes.

Based on the results of the statistical t-test (t-test), it can be concluded that the variable environment, energy, human resources, and other CSR activities do not influence earnings management. This is following the theory put forward by $\mathrm{Li}$ and Zaiats (2017) that the environment and energy are a spatial unit that affects the function of the environment alone, while Morris (2015) argues that human resources are assets that must be trained. Its capabilities are developed so that companies that do more disclosure on this dimension only want to get the attention of the surrounding community to cover up the company's opportunistic behavior.

Based on the results of the statistical t-test (t-test), it can be concluded that the variable Product, Services, Safety, \& Innovation has a positive and significant influence on earnings management. This is in line with the explanation from Atmaja (2020) which states that to be able to achieve competitive advantage can be done from three different parts, namely: cost leadership, differentiation in terms of production of products or services that are considered as units in the industry, and quality enhancement or products, so that disclosure of social responsibility activities related to aspects of Product, Services, Safety, \& Innovation will make the company's financial statements that are prepared to reduce manipulation by management.

Based on the results of the statistical t-test (t-test), it can be concluded that the variable community development has a positive and significant influence on earnings management. In line with Acharya and Patnaik (2018) explanation that socially, CSR and CD programs' performance can determine how much social legitimacy of stakeholders, especially the surrounding community, for the commitment, presence, and actions of the corporation in general. One of the social support or rejection of the existence of corporations is very much dependent on how 
corporate commitments and actions are towards them, which can be objectively reflected in the CSR and CD programs. Thus, companies that make disclosures on aspects of Community Development can limit their profit management practices.

Based on the results of the statistical t-test (t-test), it can be concluded that good corporate governance cannot moderate the relationship between corporate social responsibility disclosure, environment, energy, human resource, product development, and earnings management. This is in line with the information provided in research by Jordaan, De Klerk, and de Villiers (2018) and Gargouri, Shabou, and Francoeur (2010) that CSRD and some of these themes are still considered costs that reduce financial performance and implementing GCG will not have an impact on management to provide incentives. In managing earnings, and will continue to practice earnings management.

Based on the results of the statistical t-test (t-test), it can be concluded that good corporate governance can strengthen the relationship between community development and other CSR activities and earnings management. The implementation of GCG, which in this case is related to transparency, will further strengthen the relationship with the disclosure of corporate social responsibility related to aspects of Community Development and other CSR activities carried out by the company, such as disclosure related to company activities to help the community, activities to help victims of natural disasters, and program activities. building villages, and other community-related activities. Because taking an approach to the community and not only carrying out "formative" activities can lead to less motivation to practice earnings management.

\section{CONCLUSION}

By using a panel data model to get empirical evidence of the impact of corporate social responsibility disclosure quality with good corporate governance as the moderating variable over the 2015-2019 period. The analysis results show that Product, Services, Safety, \& Innovation, and community development negatively and significantly affect earnings management. Good corporate governance strengthens community development and the other CSR activities relationship on earnings management. This proves that companies with higher earnings management levels use CSR activities to disguise opportunistic managerial behavior, but companies that make disclosures on aspects of community development can limit their earnings management. Then, the implementation of GCG, which is related to transparency, will cause less motivation to practice earnings management.

In terms of practical implications, the results of this study will be helpful for investors in making decisions because they can provide insight into the transparency of expected earnings reported by the entity. The limitation of this study is the subjectivity in the assessment phase of the content analysis to determine the level of corporate social responsibility disclosure and good corporate governance. Future research could examine the relationship between CSR and earnings management on different themes such as using the GRI Standard and in a broader time frame, using a larger sample using other susceptible industries categories such as mining, transport, and agriculture to improve generalizations from the conclusions reached.

Funding: This study received no specific financial support.

Competing Interests: The authors declare that they have no competing interests.

Acknowledgement: Both authors contributed equally to the conception and design of the study.

\section{REFERENCES}

Abduh, M. M., \& Rusliati, E. (2018). Good corporate governance mechanisms for earnings management and financial performance. Journal of Business Research and Management, $11(2), 1112-1156$.

Acharya, J., \& Patnaik, S. (2018). Corporate social responsibility in community development and sustainability: Rourkela Steel Plant, a unit of SAIL, India. Asian Journal of Business Ethics, 7(1), 53-79. Available at: https://doi.org/10.1007/s 13520017-0079-5.

Almahrog, Y., Aribi, Z. A., \& Arun, T. (2018). Earnings management and corporate social responsibility: UK evidence. Journal of Financial Reporting and Accounting, 16(2), 311-332. Available at: https://doi.org/10.1108/JFRA-1 1-2016-0092. 
Andrian, T., \& Sudibyo, Y. A. (2019). Disclosure effect of carbon emission and corporate social responsibility to financial performance. Disclosure, 1O(12), 87-94. Available at: https://doi.org/10.7176/jesd/10-12-09.

Angelia, D., \& Suryaningsih, R. (2015). The effect of environmental performance and corporate social responsibility disclosure towards financial performance (Case study to manufacture, infrastructure, and service companies that listed at Indonesia stock exchange). Procedia-Social and Behavioral Sciences, 211, 348-355. Available at: https://doi.org/10.1016/j.sbspro.2015.11.045.

António, D. S. G. V., \& Dos Santos, F. J. M.-H. (2019). Energy management system ISO 50001: 2011 and energy management for sustainable development. Energy Policy, 133, 110868.

Atmaja, T. B. K. A. B. (2020). The influence of business strategy on earnings management with company performance as an intervening variable. E-Jra, 9(1), 273-280.

Beekes, W., Brown, P., \& Zhang, Q. (2012). Corporate governance and the informativeness of disclosures in Australia: A reexamination. SSRN Electronic Journal, 55(4), 931-963.

Burghleh, M. M. K., \& Al-Okdeh, S. K. (2020). The impact of family ownership concentration on the relationship between the characteristics of board of directors and earnings management. Management Science Letters, 10(5), 969-978.

Christensen, D. M. (2016). Corporate accountability reporting and high-profile misconduct. The Accounting Review, 91(2), 377399. Available at: https://doi.org/10.2308/accr-51200.

García-Sánchez, I. M., Hussain, N., Khan, S. A., \& Martínez-Ferrero, J. (2020). Managerial entrenchment, corporate social responsibility, and earnings management. Corporate Social Responsibility and Environmental Management, 27(4), 18181833. Available at: https://doi.org/10.1002/csr.1928.

Gargouri, R. M., Shabou, R., \& Francoeur, C. (2010). The relationship between corporate social performance and earnings management. Canadian Journal of Administrative Sciences/Revue Canadienne Des Sciences De l'Administration, 27(4), 320334. Available at: https://doi.org/10.1002/cjas.178.

Gras-Gil, E., Palacios Manzano, M., \& Hernández Fernández, J. (2016). Investigating the relationship between corporate social responsibility and earnings management: Evidence from Spain. BRQ Business Research Quarterly, 19(4), 289-299.

Grimaldi, F., Caragnano, A., Zito, M., \& Mariani, M. (2020). Sustainability engagement and earnings management: The Italian context. Sustainability, 12(12), 1-16. Available at: https://doi.org/10.3390/su12124881.

Gujarati, D. (2012). Gujarati econometric by example. London: Macmillan.

Gunawan, J. (2013). Determinant factors of corporate social disclosures in Indonesia. Issues in Social \& Environmental Accounting; $7(2), 113$. Available at: http://dx.doi.org/10.22164/isea.v7i2.78.

Hendra, J., Koesharjono, H., \& Priantono, S. (2018). Implication of good corporate governance and leverage on earnings management. International Journal of Social Science and Business, 2(1), 1-9. Available at: https://doi.org/10.23887/ijssb.v2i1.12936.

Jensen, M. C., \& Meckling, W. H. (1976). Theory of the firm: Managerial behavior, agency costs and ownership structure. Journal of Financial Economics, 3(4), 305-360.

Jones, T. M. (1995). Instrumental stakeholder theory: A synthesis of ethics and economics. Academy of Management Review, 20(2).

Jordaan, L. A., De Klerk, M., \& de Villiers, C. J. (2018). Corporate social responsibility and earnings management of South African companies. South African Journal of Economic and Management Sciences, 21(1), 1-13. Available at: https://doi.org/10.4102/sajems.v21i1.1849.

Jouber, H. (2019). Corporate social responsibility and earnings quality: Do institutional features matter? Journal of Global Responsibility, 11(1), 54-92. Available at: https://doi.org/10.1108/jgr-04-2019-0041.

Kim, Y., Park, M. S., \& Wier, B. (2012). Is earnings quality associated with corporate social responsibility? The Accounting Review, 87(3), 761-796. Available at: https://doi.org/10.2308/accr-10209.

Kim, Y. C., Seol, I., \& Kang, Y. S. (2018). A study on the earnings response coefficient (ERC) of socially responsible firms: Legal environment and stages of corporate social responsibility. Management Research Review, 41(9), 1010-1032. Available at: https://doi.org/10.1108/mrr-01-2017-0024.

Larastomo, J., Perdana, H. D., Triatmoko, H., \& Sudaryono, E. A. (2016). The influence of corporate governance and tax avoidance on earnings management in manufacturing companies in Indonesia. Essence: Journal of Business and Management, 6(1), 63-74. Available at: https://doi.org/10.15408/ess.v6i1.3121.

Li, T., \& Zaiats, N. (2017). Information environment and earnings management of dual class firms around the world. Journal of Banking Eं Finance, 74, 1-23. Available at: https://doi.org/10.1016/j.jbankfin.2016.09.009.

Mahdalena, N., Putra, A. P., \& Arnawati Putri, G. (2019). The effect of corporate governance, ownership structure and leverage on earnings management (Study of Go Public Mining Companies listed on the Indonesia Stock Exchange 2015-2018). Dewantara Management, 1(1), 181-191. Available at: https://doi.org/10.26460/md.v3i1.7658.

Mersni, H., \& Othman, H. B. (2016). The impact of corporate governance mechanisms on earnings management in Islamic banks in the Middle East region. Journal of Islamic Accounting and Business Research, 7(4), 318-348. Available at: https://doi.org/10.1 108/jiabr-11-2014-0039.

Mohmed, A., Flynn, A., \& Grey, C. (2019). The link between CSR and earnings quality: evidence from Egypt. Journal of Accounting in Emerging Economies, 10(1), 1-20. Available at: https://doi.org/10.1108/JAEE-10-2018-0109.

Montani, D., Perrini, F., Gervasio, D., \& Pulcini, A. (2020). The "Quantitative discretion index": A new business ethics tool to prevent opportunistic earnings management practices. Journal of Management and Sustainability, 10, 96-112. Available at: https://doi.org/10.5539/jms.v10n1p96.

Morris, C. (2015). An industry analysis of the power of human capital for corporate performance: evidence from South Africa. South African Journal of Economic and Management Sciences, 18(4), 486-499. Available at: https://doi.org/10.17159/2222-3436/2015/v18n4a4.

Muñoz-Torres, M. J., Fernández-Izquierdo, M. Á., Rivera-Lirio, J. M., \& Escrig-Olmedo, E. (2019). Can environmental, social, and governance rating agencies favor business models that promote a more sustainable development? Corporate Social Responsibility and Environmental Management, 26(2), 439-452. Available at: https://doi.org/10.1002/csr.169. 
Muttakin, M. B., Khan, A., \& Azim, M. I. (2015). Corporate social responsibility disclosures and earnings quality: Are they a reflection of managers' opportunistic behavior? Managerial Auditing Journal, 30(3), 277-298. Available at: https://doi.org/10.1108/MAJ-02-2014-0997.

Rusdiyanto, \& Narsa, I. M. (2020). The effect of company size, leverage and return on asset on earnings management: Case study Indonesian. Magazine Spaces, 41(17), 25-35.

Sastrawati, W., \& Hatane, S. E. (2016). Analysis of the effect of corporate governance on earnings management practices. Business Accounting Reviere, 5(1), 253-265.

Scholtens, B., \& Kang, F. C. (2013). Corporate social responsibility and earnings management: Evidence from Asian economies. Corporate Social Responsibility and Environmental Management, 20(2), 95-112. Available at: https://doi.org/10.1002/csr.1286.

Sial, M. S., Chunmei, Z., \& Khuong, N. V. (2019). Do female and independent directors explain the two-way relationship between corporate social responsibility and earnings management of Chinese listed firms? International Journal of Accounting and Information Management, 27(3), 442-460. Available at: https://doi.org/10.1108/IJAIM-03-2018-0027.

Stubben, S. R. (2010). Discretionary revenues as a measure of earnings management. The Accounting Reviere, 85(2), 695-717. Available at: https://doi.org/10.2308/accr.2010.85.2.695.

Suripto, S. (2019). Corporate social responsibility and creating shared value: A preliminary study from Indonesia. International Journal Of Contemporary Accounting, 1(1), 23-36. Available at: https://doi.org/10.25 105/ijca.v 1i1.5183.

Ulum, I., Ghozali, I., \& Chariri, A. (2008). The company's intellectual capital and financial performance; an analysis with partial least squares approach. National Symposium on Accounting, 19(19), 1-31.

Utamy, R., Ahmad, S., \& Eddy, S. (2020). Implementation of human resource management. Journal of Education Research, 1(3), 225-236. Available at: https://doi.org/10.37985/jer.v1i3.26.

Wang, X., Cao, F., \& Ye, K. (2018). Mandatory corporate social responsibility (CSR) reporting and financial reporting quality: Evidence from a quasi-natural experiment. Journal of Business Ethics, 152(1), 253-274. Available at: https://doi.org/10.1007/s10551-016-3296.

Weygandt, K., \& Kieso. (2015). Financial accounting IFRS Edition. United States of America: Pearson.

Views and opinions expressed in this article are the views and opinions of the author(s), International Journal of Sustainable Development E World Policy shall not be responsible or answerable for any loss, damage or liability etc. caused in relation to/arising out of the use of the content. 